\title{
Evaluation of Fungal Laccase Immobilized on Natural Nanostructured Bacterial Cellulose
}

\author{
Lin Chen ${ }^{1,2}$, Min Zou ${ }^{1}$ and Feng F. Hong ${ }^{1,2 *}$ \\ ${ }^{1}$ Group of Microbiological Engineering and Industrial Biotechnology, College of Chemistry, Chemical Engineering, and \\ Biotechnology, Donghua University, Shanghai, China, ${ }^{2}$ Key Laboratory of High Performance Fibers and Products, Ministry of \\ Education, Donghua University, Shanghai, China
}

The aim of this work was to assess the possibility of using native bacterial nanocellulose (BC) as a carrier for laccase immobilization. BC was synthesized by Gluconacetobacter xylinus, which was statically cultivated in a mannitol-based medium and was freezedried to form BC sponge after purification. For the first time, fungal laccase from Trametes versicolor was immobilized on the native nanofibril network-structured $\mathrm{BC}$ sponge through physical adsorption and cross-linking with glutaraldehyde. The properties including morphologic and structural features of the BC as well as the immobilized enzyme were thoroughly investigated. It was found that enzyme immobilized by cross-linking exhibited broader $\mathrm{pH}$ operation range of high catalytic activity as well as higher running stability compared to free and adsorbed enzyme. Using ABTS as substrate, the optimum $\mathrm{pH}$ value was 3.5 for the adsorption-immobilized laccase and 4.0 for the crosslinking-immobilized laccase. The immobilized enzyme retained $69 \%$ of the original activity after being recycled seven times. Novel applications of the BC-immobilized enzyme tentatively include active packaging, construction of biosensors, and establishment of bioreactors.

Keywords: bacterial cellulose, laccase, adsorption, cross-linking, immobilization

\section{INTRODUCTION}

Laccase (benzenediol:oxygen oxidoreductase, EC 1.10.3.2) is a multi-copper oxidase that is widely distributed in plants and certain fungi (Reinhammar, 1997). Laccase catalyzes the one-electron oxidation of a variety of aromatic compounds, in particular phenols, as well as diamines and hexacyanoferrate, concomitantly with the four-electron reduction of molecular oxygen to water. However, in the presence of low-molecular mass mediators, laccase can be employed for the oxidation of a variety of non-phenolic aromatic compounds (Hong et al., 2006; Riva, 2006; Cañas and Camarero, 2010). Thus, laccases have very broad substrate specificity with regard to the reducing substrate and have an interesting potential as industrial enzymes. Laccases are attracting considerable interest for a variety of biotechnological applications, such as in organic synthesis/transformation, textile processing, food industry, pharmaceutical industry, remediation of contaminated environments, delignification of pulp, modification of lignocellulosic materials, manufacture of new materials, as well as construction of biosensors and biofuel cells (Couto and Toca-Herrera, 2006; Munari et al., 2007; Rita et al., 2008; Litescu et al., 2010; Majeau et al., 2010; Kudanga et al., 2011). 
Like many other enzymes, laccases are usually limited in practical applications due to their short lifetimes and due to that they are difficult to recover from the reaction system, which might cause high processing cost. To resolve this, enzyme immobilization on insoluble supports is often proposed owing to many advantages such as ready reutilization of the catalyst and possibility of continuous operation. Laccase has been reported to be immobilized on many kinds of carriers, e.g., kaolinite (Hu et al., 2007), ceramic honeycomb (Plagemann et al., 2011), mesostructured silica materials including magnetic mesoporous spheres, or nanoparticles (Zhu et al., 2007; Bautista et al., 2010; Wang et al., 2010) and cellular foams (Rekuć et al., 2009; Zhao et al., 2011), polymer beads (Arica et al., 2009; Makas et al., 2010), agroindustrial residues including coconut fiber (Cristovao et al., 2011) and beer spent grain (da Silva et al., 2012), ionic liquid-modified cellulose acetate (Moccelini et al., 2011), membranes based on epoxy resin (Chawla et al., 2011), chemically modified polypropylene (Georgieva et al., 2010), copper ion-chelated chitosan (Bayramoglu et al., 2012), and plasma-treated cellulosic or polyamide materials (Labus et al., 2012). Immobilization based on these methods either utilize organically synthesized materials, where some organic solvents may be not environmentally friendly, or require laborious operation procedures which give low efficiency in enzyme immobilization.

Bacterial cellulose (BC) is a kind of natural cellulose synthesized by some bacteria, especially Gluconacetobacter xylinus (formerly Acetobacter xylinus) (Bielecki et al., 2002). Although chemically identical to plant cellulose, BC is characterized by a unique fibrillar nanostructure which determines its distinguished physical and mechanical properties such as high porosity, large surface area, excellent mechanical strength and good biocompatibility (Bielecki et al., 2002; Gama et al., 2012). Therefore, BC has been used widely for making high-quality audio membranes, electronic paper, membranes for fuel cells, and biomedical materials (Bielecki et al., 2002; Shah and Brown, 2005; Klemm et al., 2006; Petersen and Gatenholm, 2011; Gama et al., 2012; Jiang et al., 2012, 2015; Hong et al., 2015; Tang et al., 2015). Already today, several attempts including development of cost-effective feedstocks from agroindustrial residues (Hong et al., 2011, 2012; Cavka et al., 2013; Chen et al., 2013; Guo et al., 2013, 2015) and establishment of new cultivation methods (Sani and Dahman, 2010) have been made to decrease the production cost of BC. More applications for BC are likely to emerge if the material would become less expensive. To the best of our knowledge, there are no previous studies on immobilization of laccase on nanostructured BC.

For enzyme immobilization, the nanostructured BC material is expected to easily entrap enzyme molecules and achieve high protein loadings because of its large surface area and high porosity. Recent research indicates that untreated or unmodified cellulose-based materials are not capable of immobilizing enzyme. For example, untreated and plasma-treated cellulosic membranes were unsuitable for laccase and tyrosinase immobilization (Labus et al., 2012), and only chemically modified BC pellets (not pristine BC) have successfully been used for glucoamylase immobilization by covalent attachment
(Wu and Lia, 2008). Laccase is an enzyme with great biotechnological potential. Therefore the investigation on immobilization of the enzyme using natural BC as a support is highly meaningful because of its novelty, operational convenience, and environmental advantages.

In this work, a BC hydrogel membrane was prepared by G. xylinus grown in a mannitol-based medium, and was then freeze-dried to a sponge to maintain its native and unique fibrillar nanostructured network. The spongy membrane, which was prepared without any pretreatment or chemical derivatization, was utilized as the support to immobilize a fungal laccase from Trametes versicolor by physical adsorption and by cross-linking. Although the properties of the BC polymer are well-known and the methodologies for enzyme immobilization using adsorption and glutaraldehyde-crosslinking are mature, this is the first time that an enzyme is immobilized on natural nanostructured $\mathrm{BC}$, in a way so that the unique ultrafine fibrillar networks of $\mathrm{BC}$ are fully utilized. The properties of the $\mathrm{BC}$ and the factors influencing enzyme immobilization were thoroughly investigated. A range of characteristics including optimum catalytic conditions and reuse stability of the immobilized laccases were evaluated and compared with those of free enzyme. The proposed method has several potential benefits including utilization of an environmentally benign and sustainable material, convenience of immobilization using a simple method, improvement of enzyme performance, as well as excellent wet mechanical strength suitable for long-term running in film bioreactors.

\section{MATERIALS AND METHODS}

\section{Materials}

Laccase from $T$. versicolor and 2,2'-azino-bis-(3- ethylbenzthiazoline-6-sulfonic acid) (ABTS) was obtained from SigmaAldrich (Steinheim, Germany). The other chemicals were of analytical grade and commercially available. Determination of laccase activity was performed spectrophotometrically at $414 \mathrm{~nm}$ according to a previous study (Hong et al., 2002). One unit of laccase activity corresponds to the amount of enzyme which forms $1 \mu \mathrm{mol}$ radical cation of ABTS per minute at $\mathrm{pH} 5.2$ and $30^{\circ} \mathrm{C}$.

\section{Preparation of BC Membrane by Bacterial Cultivation}

An acetic acid bacterium, G. xylinus (formerly Acetobacter xylinus) ATCC 23770 was obtained from American Type Culture Collection (Manassas, VA, USA) and used in this study to prepare BC membranes. The culture medium adopted here was mannitol medium, which contained $25 \mathrm{~g} / \mathrm{L} \mathrm{D}$-mannitol, $5 \mathrm{~g} / \mathrm{L}$ yeast extract and $3 \mathrm{~g} / \mathrm{L}$ tryptone with the $\mathrm{pH}$ value of 5.0 , and was sterilized by autoclaving at $121^{\circ} \mathrm{C}$ (Hong et al., 2011). The bacteria were grown in a $500 \mathrm{~mL}$ flask containing $100 \mathrm{~mL}$ of the mannitol medium and cultivated at $30^{\circ} \mathrm{C}$ statically for 7 days. After cultivation, BC membranes were obtained. 


\section{Purification of Bacterial Cellulose Membrane}

After cultivation, the $\mathrm{BC}$ membrane was collected, washed with deionized water and incubated in $0.1 \% \mathrm{NaOH}$ at $80^{\circ} \mathrm{C}$ for $2 \mathrm{~h}$ in order to remove the bacterial cells and residual culture medium embedded in the BC. Thereafter BC membrane was washed in deionized water and incubated again in fresh $0.1 \% \mathrm{NaOH}$ at $80^{\circ} \mathrm{C}$ for $2 \mathrm{~h}$. Afterward BC was washed by deionized water until the $\mathrm{pH}$ value of the washing liquid became neutral. Finally, the wet membrane was freeze-dried for $24 \mathrm{~h}$ and cut into small pieces with a size of $7 \mathrm{~mm} \times 7 \mathrm{~mm}$ to $20 \mathrm{~mm} \times 20 \mathrm{~mm}$. The resulting samples were used for enzyme immobilization.

\section{Immobilization of Laccase}

In general, laccase immobilization by adsorption was carried out (Hong et al., 2010) as follows: freeze-dried BC samples was placed into $10 \mathrm{~mL}$ of laccase aqueous solution (1000 U/L, pH 5.0) and incubated at $23^{\circ} \mathrm{C}$ and $80 \mathrm{rpm}$ for $5 \mathrm{~min}$, then was placed in a $4^{\circ} \mathrm{C}$ fridge statically for $24 \mathrm{~h}$ to equilibrate. Afterward the $\mathrm{BC}$ gels were filtered out. The surface of the gels were rinsed 1-2 times quickly with sodium acetate buffer $(\mathrm{pH} 5.2,200 \mathrm{mM})$ and dried by tissue paper.

The enzyme immobilized by cross-linking was prepared with the same mixture in the adsorption method, and the mixture was incubated at $4^{\circ} \mathrm{C}$ and $80 \mathrm{rpm}$ for $24 \mathrm{~h}$. After that, $0.5 \mathrm{~mL}$ of $2.5 \%$ glutaraldehyde solution was added in the mixture and treated under at $30^{\circ} \mathrm{C}$ and $100 \mathrm{rpm}$ for $2 \mathrm{~h}$. Finally, the gels were filtered out, and treated using the same procedure as in the adsorption method.

\section{Assay of Immobilized Laccase Activity}

The laccase activity was measured using ABTS $\left(\varepsilon_{\mathrm{ABTS}}=36,000 \mathrm{M}^{-1} \cdot \mathrm{cm}^{-1}\right)$ as substrate (Hong et al., 2002). One activity unit was defined as the amount of enzyme that oxidized $1 \mu \mathrm{mol}$ of ABTS per min. In a typical experiment, $20 \mathrm{~mL}$ of reaction medium composed of $0.4 \mathrm{mM} \mathrm{ABTS}$ and $50 \mathrm{mM}$ sodium acetate buffer ( $\mathrm{pH}$ 5.2) was placed into a $100 \mathrm{~mL}$ screw-capped vial, which was incubated in a $30^{\circ} \mathrm{C}$ water bath with $220 \mathrm{rpm}$ agitation on a magnetic stirrer. The reaction was started by adding free or immobilized laccase. Aliquots were withdrawn from the reaction mixture at different reacting intervals and analyzed spectrophotometrically at $414 \mathrm{~nm}$. For the immobilized enzyme, sampling started after $10 \mathrm{~min}$. The activity of immobilized laccase was calculated using the following equation (1). Triplicate experiments for each sample were carried out and mean values are given. Analysis of variance (ANOVA) was performed and $P$ value is given.

[Activity of immobilized laccase $(\mathrm{U} / \mathrm{g} B \mathrm{BC})=$

$$
\left.\frac{k \times V_{\text {Total }} \times 10^{6}}{M_{B C} \times \varepsilon}\right],
$$

where $k$ is the slope of the plot of the absorbance changes at $414 \mathrm{~nm}$ versus reaction time,

$V_{\text {Total }}$ is the total volume of reaction medium $(0.02 \mathrm{~L})$,

$M_{B C}$ is the mass of BC support of immobilized laccase (g), $\varepsilon$ is the extinction coefficient of ABTS $\left(\varepsilon_{\mathrm{ABTS}}=36,000\right.$ $\left.\mathrm{M}^{-1} . \mathrm{cm}^{-1}\right)$.

[Adsorption ratio of laccase $(\%)=$

[Total activity of free laccase $(\mathrm{U})$ - Total residual

activity of free laccase after immobilization (U)]

$\div$ Total activity of free laccase $(\mathrm{U}) \times 100]$

[Recovery of laccase activity $(\%)=$

Total activity of immobilized laccase (U)

$\div$ Total activity of free laccase $(\mathrm{U}) \times 100]$

$[$ Specific activity $(\mathrm{U} / \mathrm{mg}$ protein $)=$

Activity of immobilized laccase (U/g BC)

$\div$ Protein loading $(\mathrm{mg} / \mathrm{g} \mathrm{BC}]$

\section{Reusability of the Immobilized Laccases}

According to the assay protocol for laccase activity, immobilized laccases were added to initialize the first reaction. After the reaction, the immobilized enzymes were separated by filtration and then rinsed with $50 \mathrm{mM}$ sodium acetate buffer $(\mathrm{pH}$ 5.2) until the washing water was colorless. The second reaction was started by adding the washed immobilized laccase in a new reaction medium composed of $0.4 \mathrm{mM}$ ABTS and $50 \mathrm{mM}$ sodium acetate buffer ( $\mathrm{pH}$ 5.2). The repeated reactions were run several times to measure the residual activity of the immobilized laccase. Triplicate experiments for each sample were carried out and mean values are given. ANOVA was performed and $P$ value is given.

\section{Protein Assay}

Protein was determined according to Bradford's method (Bradford, 1976) by using BSA as a standard. The amount of bound protein in $\mathrm{BC}$ membrane was determined indirectly by comparing the difference between the total amount of protein introduced into the reaction medium and the amount of protein in the filtrate. Very little protein could be found in the washing solutions after immobilization and it could therefore be ignored. Protein loading was calculated using equation (5). Triplicate experiments for each sample were carried out and mean values are given. ANOVA was performed and $P$ value is given.

$$
\begin{aligned}
& \text { [Protein loading }(\mathrm{mg} / \mathrm{g} \mathrm{BC})= \\
& \quad[\text { Total protein of free laccase }(\mathrm{mg})-\text { Total residual } \\
& \text { protein of free laccase after immobilization }(\mathrm{mg})] \\
& \quad \div \text { Total mass of } \mathrm{BC} \text { support }(\mathrm{g})]
\end{aligned}
$$

\section{Characterization}

Scanning electron microscopy (SEM, S-4800 Hitachi Ltd., Japan) was applied for morphologic observation. Prior to the inspection, the lyophilized BC sample was coated with gold. The structural features of $\mathrm{BC}$ were further investigated by X-ray diffraction using a D/Max-2550PC diffractometer at $40 \mathrm{kV}$ and $200 \mathrm{~mA}$. 
Angular scanning was continued $5^{\circ}$ to $60^{\circ}(2 \theta)$ at $1^{\circ} / \mathrm{min}$. The crystalline index $\left(\mathrm{CrI}^{\mathrm{XRD}}\right)$ was calculated using an empirical method for native cellulose: $\mathrm{CrI}^{\mathrm{XRD}}=\left(\mathrm{I}_{200}-\mathrm{I}_{\mathrm{am}}\right) / \mathrm{I}_{200} \times 100 \%$, where $I_{200}$ is the maximum intensity of the (200) lattice diffraction and $\mathrm{I}_{\mathrm{am}}$ is the intensity diffraction at $2 \theta=18^{\circ}$ (Focher et al., 2001). The pore size and surface area of the dry BC sponge sample were determined with a Brunauer-EmmettTeller (BET) surface area analyzer (ASAP 2020 - Physisorption Analyzer, Micromeritics Instrument Corporation, GA). Before determination, the accurately weighed freeze-dried samples were put in sample tubes and heated at $90^{\circ} \mathrm{C}$ under vacuum for $3 \mathrm{~h}$ to remove surface moisture and other contaminants and cooled to room temperature before the BET analysis. The BET analysis was done with a relative vapor pressure of $0.05-0.25$. The BET pore size and surface area were determined with $\mathrm{N}_{2}$ adsorption at $77 \mathrm{~K}$. Quintuplicate experiments for each sample were carried out and mean values are given.

\section{RESULTS AND DISCUSSION}

\section{Structural Properties of BC Membranes}

Figure 1 shows the scanning electron micrograph of the spongy BC membrane produced by G. xylinus. From the picture, it could be seen that the $\mathrm{BC}$ membrane had a reticulated structure consisting of ultrafine cellulose fibrils with a diameter of less than $100 \mathrm{~nm}$, which resulted in large surface area. The pore size and the surface area of the BC membranes were determined by using the BET method. The results showed that the average pore size, the pore volume and the surface area of the BC sponge were $11.5 \mathrm{~nm}, 0.25 \mathrm{~cm}^{3} / \mathrm{g}$, and $72.2 \mathrm{~m}^{2} / \mathrm{g}$, respectively. This structure will generate a hydrogel (a hydrated membrane) when the $\mathrm{BC}$ sponge is placed in water or aqueous solution of solutes. Sokolnicki et al. (2006) showed that BC would have a high swelling ratio of 17.9 and a high porosity of 0.94 , indicating that defined cylindrical pores do not exist while instead microchannels of varying sizes are present. It is concluded that the high surface area and porous features of BC membrane should provide micro-channels to entrap enzyme and improve the contact area exposed to enzyme protein molecules, and hence increase the amount of bound protein. The structural features of BC were also studied by using XRD (Figure 2). Figure 2 shows three diffraction peaks at around $15.0^{\circ}, 16.5^{\circ}$, and $22.8^{\circ}$, the presence of which were attributed to the typical profile of cellulose I (natural cellulose) in crystalline form (Atalla and Vanderhart, 1984). A crystallinity of $86.9 \%$ was obtained by calculation of the crystalline index $\left(\mathrm{CrI}^{\mathrm{XRD}}\right)$.

\section{Effects of Size of BC Membranes on Laccase Immobilization}

Lyophilized spongy BC membranes were cut into several pieces with the sizes $(\mathrm{mm} \times \mathrm{mm})$ of $7 \times 7,10 \times 10,15 \times 15$, and $20 \times 20$. An experiment was performed to study the effects of the size of $\mathrm{BC}$ on laccase immobilization by putting these $\mathrm{BC}$ pieces in $10 \mathrm{~mL}$ of a laccase-containing aqueous solution that was incubated statically for $24 \mathrm{~h}$. Triplicate experiments for each sample were carried out and mean values are given in Table $\mathbf{1 .}$

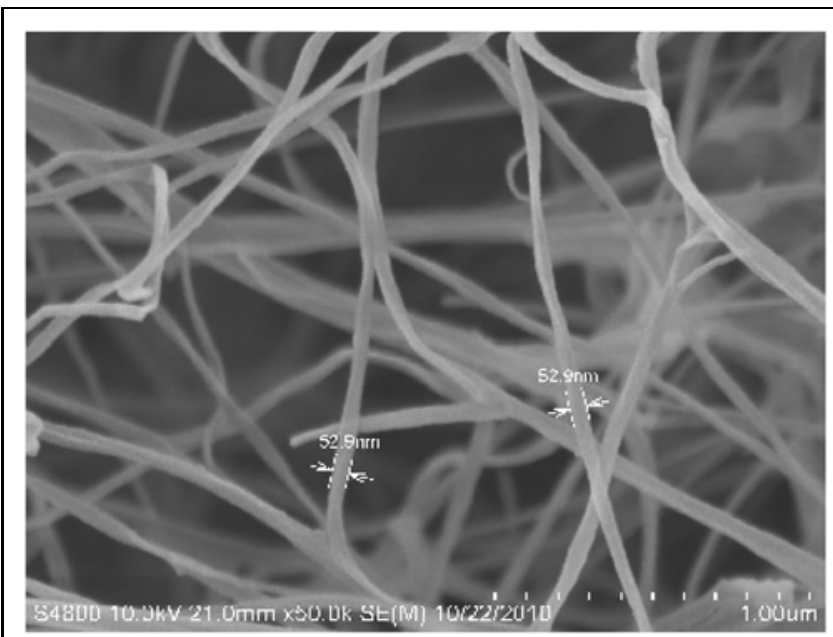

FIGURE 1 | Scanning electron micrograph of the foam-like bacterial cellulose $(\mathrm{BC})$ membrane produced by Gluconacetobacter xylinus $(\times 50,000)$.

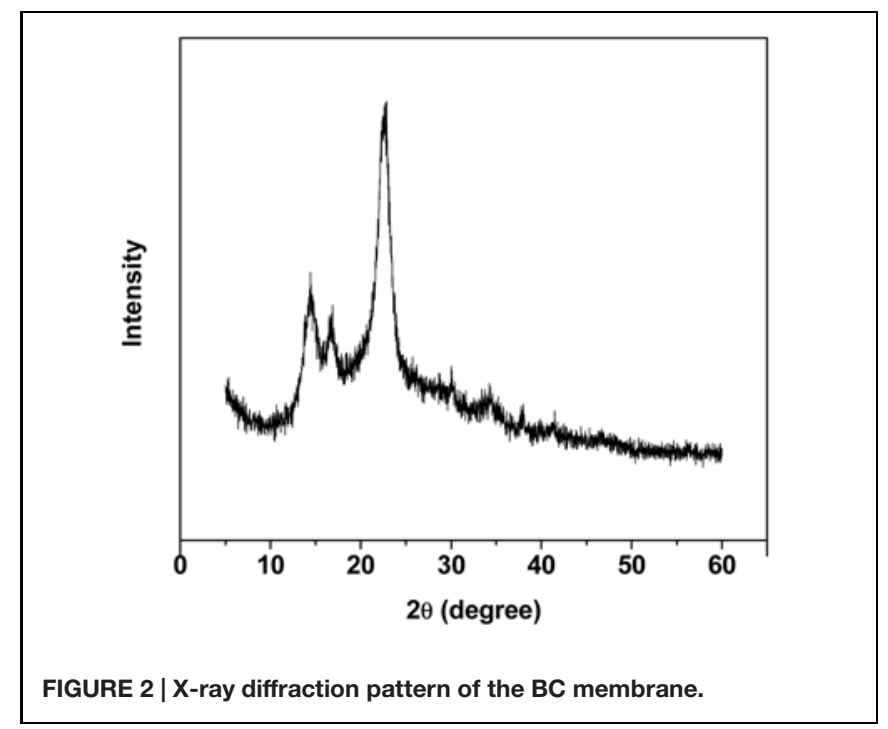

Table 1 shows that the adsorption ratio of enzyme and the recovery of the laccase activity increased gradually with larger size of the membrane support, while the activity of immobilized laccase and the protein loading decreased with every gram of carrier. The highest values for adsorption ratio of enzyme (39.2\%) and recovery of laccase activity (8.0\%) were obtained with a $\mathrm{BC}$ size of $20 \mathrm{~mm} \times 20 \mathrm{~mm}$. The best results for the activity of immobilized laccase $(9.7 \mathrm{U} / \mathrm{g} \mathrm{BC})$ and protein loading (3.2 $\mathrm{mg}$ protein/g BC) were obtained with the $7 \mathrm{~mm} \times 7 \mathrm{~mm}$ BC membrane. In addition, the specific activity of immobilized laccase based on adsorbed protein did not show any significant difference (from 2.6 to $3.0 \mathrm{U} / \mathrm{mg}, P>0.05$ ) among the four sizes of $\mathrm{BC}$ membranes. The enzyme loading is comparable to other reported results. Arica et al. (2009) obtained an adsorption capacity of $4.9 \mathrm{mg} / \mathrm{g}$ support when using poly(GMA/EGDMA) beads as carriers. Osma et al. (2010) reported that an activity of 
TABLE 1 | Effects of size of bacterial cellulose (BC) membranes on laccase immobilization using only physical adsorption. Triplicate experiments for each sample were carried out and mean values are given.

\begin{tabular}{|c|c|c|c|c|}
\hline BC membrane size $(\mathrm{mm} \times \mathrm{mm})$ & $7 \times 7$ & $10 \times 10$ & $15 \times 15$ & $20 \times 20$ \\
\hline $\mathrm{BC}$ mass (mg) & $2.4 \pm 0.1$ & $4.4 \pm 0.1$ & $8.7 \pm 0.2$ & $18.5 \pm 0.3$ \\
\hline Adsorption ratio of enzyme (\%) & $13.4 \pm 0.3$ & $18.6 \pm 0.5$ & $22.1 \pm 0.4$ & $39.2 \pm 0.6$ \\
\hline Recovery of laccase activity (\%) & $2.3 \pm 0.1$ & $3.7 \pm 0.2$ & $4.5 \pm 0.1$ & $8.0 \pm 0.3$ \\
\hline Activity of immobilized laccase (U/g BC) & $9.7 \pm 0.4$ & $8.4 \pm 0.3$ & $6.9 \pm 0.2$ & $5.9 \pm 0.2$ \\
\hline Protein loading (mg protein/g BC) & $3.2 \pm 0.2$ & $3.0 \pm 0.2$ & $2.7 \pm 0.1$ & $2.1 \pm 0.1$ \\
\hline Specific activity (U/mg protein) & $3.0 \pm 0.3$ & $2.8 \pm 0.3$ & $2.6 \pm 0.1$ & $2.8 \pm 0.1$ \\
\hline
\end{tabular}

immobilized laccase of $7.4 \mathrm{U} / \mathrm{g}$ support and a protein loading of $0.18 \mathrm{mg} / \mathrm{g}$ support were achieved when alumina $\left(\mathrm{Al}_{2} \mathrm{O}_{3}\right)$ spherical pellets ( $3 \mathrm{~mm}$ diameter) were used as supports. This study showed that the activity of immobilized laccase, which ranged from 5.9 to $9.7 \mathrm{U} / \mathrm{g} \mathrm{BC}$, and the protein loading, which ranged from 2.1 to $3.2 \mathrm{mg}$ protein/g BC, are comparable to those reported in the literature, indicating that the immobilization of the enzyme on $\mathrm{BC}$ was reasonable and satisfactory.

The reason behind the fact that the activity of the immobilized enzyme and the loaded protein decreased with increasing size of $\mathrm{BC}$ may be ascribed to that the amplification of enzyme protein adsorption is less than that of the $\mathrm{BC}$ mass when the size of the $\mathrm{BC}$ membranes were enlarged. Enlarging the size of $\mathrm{BC}$ cannot only augment the space for adsorption of enzyme molecules, but also increase the bulk and mass of BC. Through calculation, a mass amplification of $83 \%$ is obtained when the BC size was enlarged from $7 \times 7$ to $10 \times 10 \mathrm{~mm}^{2}$ (BC mass increased from 2.4 to $4.4 \mathrm{mg}$ ), but it is only $59 \%$ for the total activity of adsorbed laccase. In a similar way, a mass amplification of $113 \%$ and an amplification of total activity of $82 \%$ are obtained when the membrane size was enlarged from $15 \times 15$ to $20 \times 20 \mathrm{~mm}^{2}$ (BC mass was from 8.7 to $18.5 \mathrm{mg}$ ), respectively. The unbalance of amplification between adsorbed enzyme and BC mass would lead to this inconsistency.

The apparent discrepancy between adsorption ratio of enzyme and recovery of laccase activity might be ascribed to the difference in the matrices, steric hindrance of the adsorbed enzyme, differences in the methods for activity measurement, and even enzyme denaturation. Free laccase is defined as enzyme dissolved in water or buffer, leading to a quick catalytic reaction because of its easy binding with the substrate ABTS, which is also soluble in the aqueous phase during the activity assay. However, the media was changed from water for free enzyme to porous BC network filled with water for immobilized enzyme. More mass transfer resistance forms after laccase is entrapped and immobilized in the porous network of $\mathrm{BC}$ compared to the free enzyme. The mass transfer resistance decreases the binding efficiency between the enzyme and the substrate ABTS, and reduces the diffusion of the oxidized product of ABTS from the inside to the outside of the $\mathrm{BC}$ membrane. Mass transfer resistance is crucial for immobilized enzyme (Gardossi et al., 2010). Our previous research showed that the porous network of a $\mathrm{BC}$ hydrogel would determine the rate of entrapped drug release (Wei et al., 2011), and, vice versa, the network would control diffusion of chemicals from the outside to the inside of the BC. In this study, the obtained activity depends on the formation of product from the substrate ABTS molecule, which is required to diffuse from the outside into the network of $\mathrm{BC}$ to get in contact with the immobilized laccase to react and then its radical product is required to diffuse to the outside. Therefore, the activity of the immobilized laccase would depend on the diffusion coefficient and the efficiency of the substrate ABTS molecule through the highly porous network of hydrogel matrix (Figure 1). An analogous molecule of ABTS $(548.7 \mathrm{Da})$ in terms of molecular weight $(\mathrm{MW})$, Vitamin B12 $(1355 \mathrm{Da})$, had a smaller diffusivity $\left(0.72 \times 10^{-6} \mathrm{~cm}^{2} / \mathrm{s}\right)$ in the BC membranes than in water $\left(3.79 \times 10^{-6} \mathrm{~cm}^{2} / \mathrm{s}\right.$ ) (Sokolnicki et al., 2006), indicating that ABTS and the oxidized ABTS product also should have a smaller diffusivity than in water. Transport of ABTS occurs predominately through the water in the membrane with a pore mechanism, but some molecules are retarded due to partitioning into the cellulose as well as adsorption onto the membrane, as stated in the literature (Sokolnicki et al., 2006). Therefore the smaller diffusivity of ABTS leads to the lower activity determined for immobilized enzyme than for free one, whose activity was used to calculate the adsorption ratio of enzyme. The determined lower activity of immobilized laccase as compared with free laccase would undoubtedly lead to a much less recovery of activity than the adsorption ratio of laccase, but actually the authentic activity of immobilized laccase should be higher than that obtained by using the analytic method. It could be concluded that the present analytical method for determining the activity of the BC-immobilized enzyme is not good enough since it shows much lower activity recovery compared to the actual adsorption ratio of enzyme. This situation is not like that in research on nanoparticle-immobilized laccase, whose reactive behavior with substrate is similar to that of the free enzyme.

Sokolnicki et al. (2006) studied mass transport parameters of hydrated $\mathrm{BC}$ membranes including solubility, diffusion and permeability coefficients, and adsorption equilibrium partition coefficients identifying the binding of solute onto the membrane scaffolding, with the goals to quantify the transport of proteins and small molecules in the cellulose membrane and to apply an understanding of the membrane structure to determine the mechanism of transport in the system. The results indicated that there exist dual transport mechanisms, for solute transport through the continuous water phase and cellulose matrix with some hindrance of molecular diffusion via fiber obstruction. With the small solute Vitamin B12, equilibrium interactions such as adsorption and solubility are also important. The permeability 
coefficients and the effective diffusion coefficients of the solutes decreased with increasing MW of the diffusing molecules (Sokolnicki et al., 2006). In this study, the substrate ABTS is also a small molecule solute with a MW of $548.7 \mathrm{Da}$ as small as Vitamin B12. It will also have dual transport mechanisms, which determine the obtained activity of immobilized laccase. Some of the $\mathrm{ABTS}^{+}$radical molecules in the catalysis may be reversibly adsorbed onto and/or absorbed into the BC membrane fibers. This entrapment or immobilization on/within the polymer, most likely at crystalline regions and solubility in the amorphous phase, influences the interfacial velocity, requiring more time to travel the length of the membrane. When all of the interactive sites are occupied and/or solubility limits reached, free diffusion endures, as stated in the literature (Sokolnicki et al., 2006).

\section{Effects of Amount of BC Pieces on Laccase Immobilization}

Lyophilized BC membranes of $10.2 \mathrm{mg}$ were cut into 1-4 pieces and were then incubated statically in $10 \mathrm{~mL}$ laccase-containing aqueous solution for $24 \mathrm{~h}$. The experiment was performed to study the effects of the amount of $\mathrm{BC}$ pieces with the same gram of mass on laccase immobilization. Triplicate experiments for each sample were carried out and mean values are given in Table 2.

Table 2 indicates that four index points including adsorption ratio of enzyme (increased from 31.1 to $42.3 \%$ ), recovery of laccase activity (increased from 6.1 to $8.6 \%$ ), activity of immobilized laccase and protein loading all together increased gradually as the number of pieces of $\mathrm{BC}$ support increased. When the number of $\mathrm{BC}$ pieces was four, the activity of immobilized laccase and protein loading reached the highest values, i.e., $9.8 \mathrm{U} / \mathrm{g} \mathrm{BC}$ and $3.9 \mathrm{mg}$ protein/g BC, respectively. The specific activity of immobilized laccase also did not change very much among these four groups with regard to the numbers of BC pieces (from 2.3 to $2.6 \mathrm{U} / \mathrm{mg}$ ). The adsorption ratio of enzyme protein ranging from 31.1 to $42.3 \%$ is in accordance with those data (protein yield ranged from 31.5 to $41.5 \%$ ) reported in a literature (Rekuć et al., 2009).

The result implies that an increased number of $\mathrm{BC}$ pieces of the same $\mathrm{BC}$ mass corresponds to increased adsorption area and reaction surface based on the same mass. More enzyme protein can be easily adsorbed or entrapped by the shortened routes and more contacting surfaces of BC carriers for the diffusion of enzyme. This will also happen for ABTS diffusion during activity assay. A higher total activity obtained from the increased number of $\mathrm{BC}$ pieces will result in a higher activity of immobilized laccase for each gram of BC support (9.8 U/g BC was obtained by using four pieces while only $5.7 \mathrm{U} / \mathrm{g} \mathrm{BC}$ for one piece). The reason behind the difference between the adsorption ratio of laccase and the recovery of laccase activity should be due to the diffusion distance and diffusion surface of ABTS into BC, as similar as the situation in the section of 2.2. Although agitation was used in the activity measurements, the interior environment of the BC support could not be easily disturbed by agitation because of the relatively big size of the support (still being around $4 \mathrm{~mm} \times 4 \mathrm{~mm})$.

\section{Effects of Adsorption Time on Laccase Immobilization}

Freeze-dried BC membranes of $2.6 \mathrm{mg}$ were incubated in $10 \mathrm{~mL}$ of laccase-containing aqueous solution for $0.5-8 \mathrm{~h}$ and $24 \mathrm{~h}$. The experiment was performed to study the effects of the adsorption time on laccase immobilization. Triplicate experiments for each sample were carried out and mean values are given in Table 3.

Table 3 indicates that the three index points including adsorption ratio of enzyme, recovery of laccase activity, and activity of immobilized laccase all together increased gradually with prolonged adsorption time. The adsorption ratio of enzyme and recovery of laccase activity did not change significantly after $4 \mathrm{~h}$ of incubation. This is probably due to that the adsorption space of the nanostructured network of the BC was nearly fully occupied after an incubation of $4 \mathrm{~h}$. However, changes in the activity of immobilized enzyme only became negligible after $6 \mathrm{~h}$ of incubation. This result confirms that the incubation time of $24 \mathrm{~h}$ previously used is appropriate, which could ensure enough time to make enzyme proteins penetrate and diffuse into the internal network of BC carriers. A longer lag time than $2 \mathrm{~h}$ and an equilibrium time of $8 \mathrm{~h}$ required for laccase $(64 \mathrm{kDa})$ in the membranes were observed in this study, which is consistent with that a protein with similar size as laccase, BSA $(66.3 \mathrm{kDa})$, had nearly $2 \mathrm{~h}$ lag time and $8 \mathrm{~h}$ induction time (Sokolnicki et al., 2006). Solutes were found to have an induction phase followed by a free diffusion phase when the transport of BSA was evaluated in the study of permeability of BC membranes (Sokolnicki et al., 2006).

\section{pH Profiles of Immobilized Laccase}

The effects of $\mathrm{pH}$ on the activity of the free and immobilized laccase were studied in the $\mathrm{pH}$ range from 3.0 to 6.0. Figure 3 shows that the optimum $\mathrm{pH}$ value was 3.5 and 4.0 for the adsorption-immobilized and the crosslinking-immobilized laccase, respectively. For free laccase, the activity was strongly $\mathrm{pH}$-dependent and had no optimum. The free laccase showed highest activity at $\mathrm{pH} 3.0$ with ABTS (non-phenolic) as substrate, which is consistent with a previous study (Hong et al., 2006). However, after immobilization by physical adsorption, activity increased rapidly first then decreased as $\mathrm{pH}$ was increased, and the curve shape and the optimal $\mathrm{pH}$ were significantly changed (shifted from $\mathrm{pH} 3.0$ to $\mathrm{pH} 3.5, P<0.05$ ). After immobilization by adsorption-crosslinking, the optimum value shifted to $\mathrm{pH}$ 4.0. In comparison with the free laccase, the crosslinking-immobilized laccase exhibited more than $90 \%$ of the maximum activity with a wider $\mathrm{pH}$ range between 3.0 and 4.0 (Figure 3). Therefore, the immobilized laccase maintained a relatively high activity over a broader $\mathrm{pH}$ range. This means that the laccase immobilization by adsorption-crosslinking on $\mathrm{BC}$ membrane could increase the $\mathrm{pH}$ resistance of high catalytic activity within a broader $\mathrm{pH}$ range, and this property is crucial in practical applications, e.g., in the treatment of textile industrial waste effluent.

The $\mathrm{pH}$ optimum of fungal laccase is strictly dependent on the type of substrate used. For non-phenolic substrates, for example, ABTS and 2,4,5- trimethoxybenzyl alcohol, the activity of fungal laccase from $T$. versicolor always increases with decreasing $\mathrm{pH}$ 


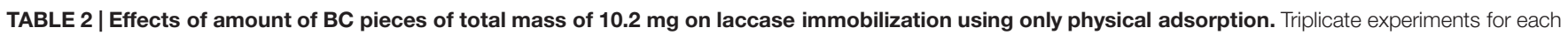
sample were carried out and mean values are given.

\begin{tabular}{|c|c|c|c|c|}
\hline Number of BC membranes & 1 & 2 & 3 & 4 \\
\hline Adsorption ratio of enzyme (\%) & $31.1 \pm 1.5$ & $35.7 \pm 1.3$ & $38.6 \pm 1.3$ & $42.3 \pm 1.5$ \\
\hline Recovery of laccase activity (\%) & $6.1 \pm 0.3$ & $6.8 \pm 0.2$ & $7.4 \pm 0.3$ & $8.6 \pm 0.3$ \\
\hline Activity of immobilized laccase (U/g BC) & $5.7 \pm 0.3$ & $7.1 \pm 0.3$ & $8.5 \pm 0.3$ & $9.8 \pm 0.2$ \\
\hline Protein loading (mg protein/g BC) & $2.4 \pm 0.2$ & $2.9 \pm 0.1$ & $3.2 \pm 0.2$ & $3.9 \pm 0.2$ \\
\hline Specific activity (U/mg protein) & $2.3 \pm 0.2$ & $2.5 \pm 0.1$ & $2.6 \pm 0.1$ & $2.5 \pm 0.1$ \\
\hline
\end{tabular}

TABLE 3 | Effects of adsorption time on laccase immobilization using only physical adsorption. Triplicate experiments for each sample were carried out and mean values are given.

\begin{tabular}{|c|c|c|c|c|c|c|c|}
\hline Adsorption time (h) & 0.5 & 1 & 2 & 4 & 6 & 8 & 24 \\
\hline Adsorption ratio of enzyme (\%) & $27.6 \pm 1.6$ & $28.4 \pm 1.4$ & $29.9 \pm 1.5$ & $34.7 \pm 1.5$ & $34.5 \pm 1.3$ & $34.7 \pm 1.5$ & $35.1 \pm 1.8$ \\
\hline Recovery of laccase activity (\%) & $0.4 \pm 0.1$ & $0.7 \pm 0.1$ & $0.9 \pm 0.1$ & $1.1 \pm 0.1$ & $1.1 \pm 0.1$ & $1.2 \pm 0.1$ & $1.2 \pm 0.2$ \\
\hline Activity of immobilized laccase (U/g BC) & $1.9 \pm 0.1$ & $3.0 \pm 0.2$ & $3.4 \pm 0.2$ & $4.8 \pm 0.2$ & $4.9 \pm 0.3$ & $5.1 \pm 0.3$ & $5.2 \pm 0.5$ \\
\hline
\end{tabular}

(monotonic $\mathrm{pH}$ profiles), but for phenols bell-shaped $\mathrm{pH}$ profiles with an optimum at $\mathrm{pH} 4$ are exhibited all the time (Hong et al., 2006). It would be interesting to investigate $\mathrm{pH}$ profiles of other substrates in the future, especially phenolic compounds, to see if the BC-immobilized enzyme will show a higher $\mathrm{pH}$ optimum than $\mathrm{pH} 4$ as with the ABTS used in this study. It is known that the optimum $\mathrm{pH}$ for an immobilized enzyme shifting to a higher or lower $\mathrm{pH}$ depends upon surface charges of the support (Zhang et al., 2012), or in other words, depends upon the ionic interaction between enzyme and charged surface of the support (Wang et al., 2010). The shift in optimum $\mathrm{pH}$ toward a less acidic $\mathrm{pH}$ value upon immobilization may be due to the difference in the hydronium ion concentration of the micro-structures of the polymeric support and in the bulk of the solution. The BC support has many hydroxyl groups on its inner surface, which could attract more hydrogen ions from reaction solution. It could be deduced that the $\mathrm{pH}$ value for the immobilized enzyme experienced a lower $\mathrm{pH}$ in the support pores of $\mathrm{BC}$ than in the reaction media, and therefore shifted to higher $\mathrm{pH}$ values (Zhang et al., 2012).

As compared to the native free enzyme, the fact that the crosslinking-immobilized laccase showed broadening in the $\mathrm{pH}$ activity profile means that the immobilization methods may preserve the enzyme activity and limit the transition of enzyme conformation in a wider $\mathrm{pH}$ range by the formation of multipoint non-covalent interactions, as reported in the literature (Arica et al., 2009; Majeau et al., 2010). This may be the reason why the optimum $\mathrm{pH}$ of immobilized enzyme was between $\mathrm{pH} 3.5$ and 4.0, while free enzyme showed a monotonic $\mathrm{pH}$ profile.

\section{Temperature Profiles of Immobilized Laccase}

The effects of temperature on the activity of the free and immobilized laccases were also studied in the temperature range of $20-70^{\circ} \mathrm{C}$ and data were shown in Figure 4. Figure 4 shows that the activities of either free or immobilized laccase increased gradually first with increasing temperature until optima and

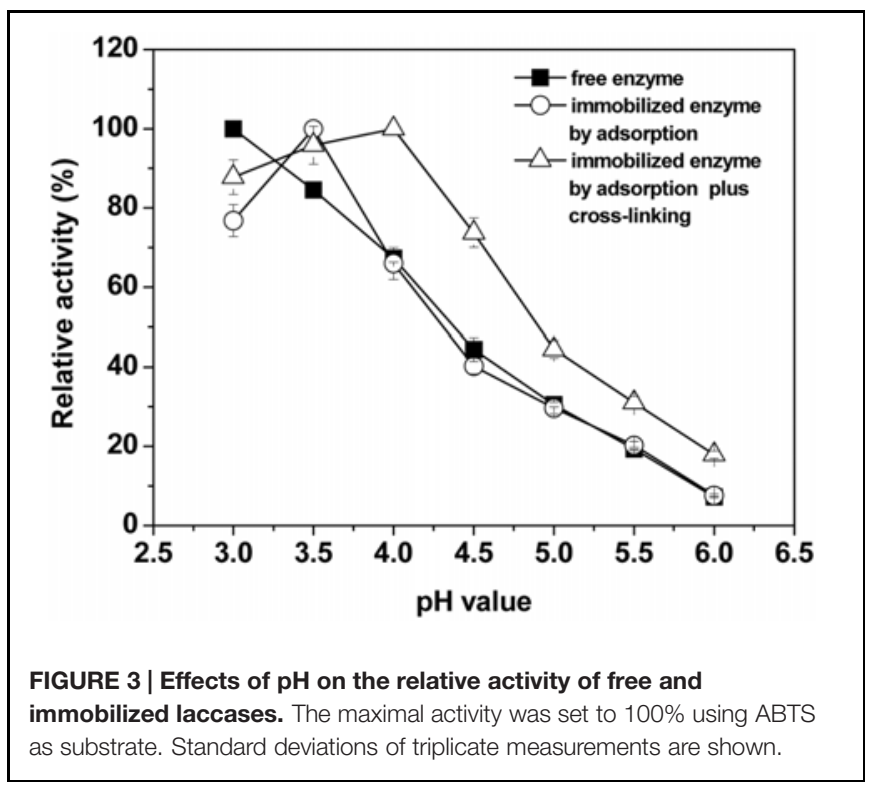

thereafter decreased with further increases of temperature. The optimal catalytic temperature of immobilized laccases was higher than that of free form and shifted from $50^{\circ} \mathrm{C}$ to $60^{\circ} \mathrm{C}$ (Figure 4). The shift of the optimum temperature indicates an increase in the thermal stability of the immobilized laccases, and this should be related to the change of physical and chemical properties of the immobilized enzymes. In particular for adsorptionimmobilization, the non-covalent multipoint chelate interactions between laccase and support may restrict the degrees of freedom of the molecular structure of the enzyme, thus protecting it to some extent from denaturation at high temperature (Wang et al., 2010; Bayramoglu et al., 2012). Furthermore, compared with the free and adsorption-immobilized laccase, the crosslinkingimmobilized enzyme exhibited a significantly broader profile $(P<0.05)$, and the relative activity was maintained at over $90 \%$ within the temperature range of $50-70^{\circ} \mathrm{C}$. The covalent 


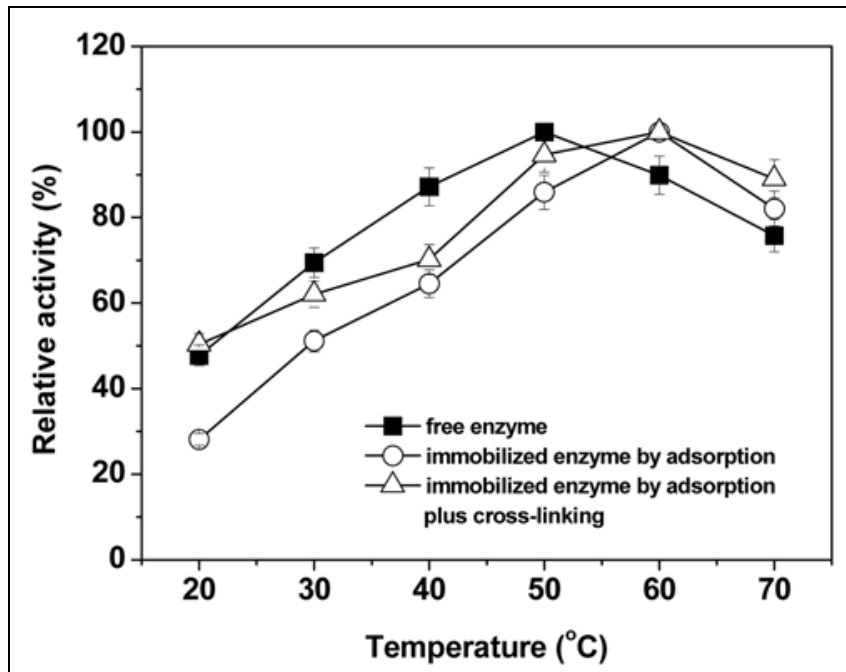

FIGURE 4 | Effects of temperature on the relative activity of free and immobilized laccase. The maximal activity was set to $100 \%$ using ABTS as substrate. Standard deviations of triplicate measurements are shown.

bond formation after crosslinking via amino groups of the immobilized laccase and hydroxyl groups of BC might also reduce the conformational flexibility and may result in higher activation energy for the enzyme molecule to reorganize the proper conformation for the binding of the substrate (Arica et al., 2009; Zhang et al., 2012).

\section{Reusability of Immobilized Laccase}

The reusabilities of laccase immobilized on BC membrane by the two methods were studied in this test. The original activity of the immobilized enzyme was defined as $100 \%$ with a value of $6.2 \mathrm{U} / \mathrm{g}$ BC. As seen in Figure 5, significant improvement $(P<0.01)$ of operational stability could be observed with the crosslinking-immobilized laccase compared to that immobilized only by physical adsorption. The former enzyme retained $69 \%$ of the original activity after recycling seven times, while only $23 \%$ residual activity remained for the latter. This is due to that the adsorption method just supplied a relative poor interaction between the enzyme and the carrier, whereas the cross-linking treatment by glutaraldehyde after adsorption significantly decreased the loss of enzyme protein during reaction because of diffusion, and subsequently improved the operational stability of enzyme. This result is comparable with that in a research, which showed $78 \%$ of the initial activity of the immobilized T. villosa laccase remained after four cycles (Zhang et al., 2012). The results also showed that there was a gradual decrease after every cycle because of loss of a small amount of enzyme immobilized on BC or possible inactivation of enzyme in each cycle.

As Sokolnicki et al. (2006) indicated for permeability of BC membranes, the dual transport mechanism for solute transport in the continuous water phase (pore mechanism) and cellulose matrix with some hindering of molecular diffusion via fiber obstruction should also be applicable here with respect to the

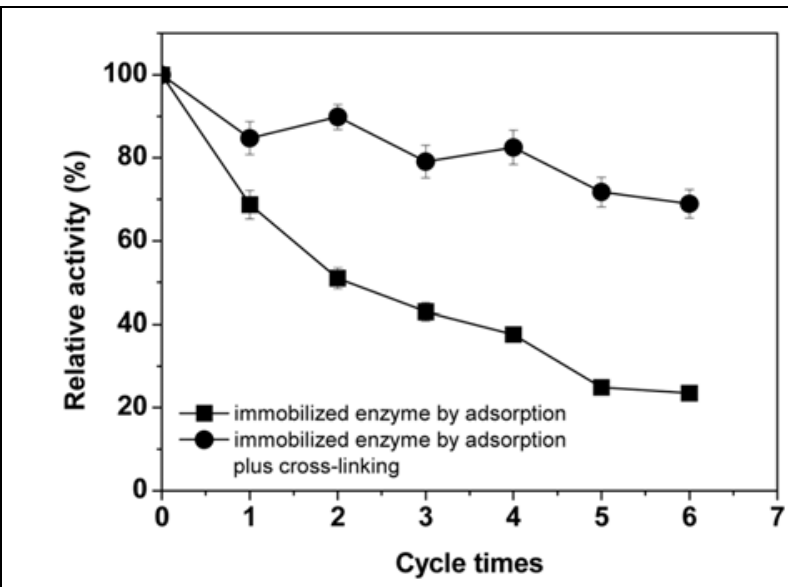

FIGURE 5 | The reuse stability of the immobilized laccases. Standard deviations of triplicate measurements are shown.

diffusion of laccase immobilized in BC membranes. BSA has a size of $66.3 \mathrm{kDa}$ and has a smaller diffusivity $\left(0.09 \times 10^{-6} \mathrm{~cm}^{2} / \mathrm{s}\right)$ in the BC membranes than in water $\left(0.59 \times 10^{-6} \mathrm{~cm}^{2} / \mathrm{s}\right)$ (Sokolnicki et al., 2006), which implies that a laccase of around $64 \mathrm{kDa}$ (Hong et al., 2002) should similarly have a small diffusivity. Diffusion with the zero solubility of BSA in the membrane, hydrodynamic and entropic exclusions account for the high degree of hindrance of BSA due to its large MW and hydrodynamic radius (Sokolnicki et al., 2006). Like BSA, no adsorption occurring within or on the fiber networks, diffusion of the laccase within $\mathrm{BC}$ to outside occurs entirely through the water-filled channels (pore mechanism) and thereafter would lead to the activity loss of the adsorption-immobilized enzyme. But the hindered diffusion of laccase in the $\mathrm{BC}$ membrane due to fiber obstruction would restrict the loss of activity of the immobilized enzyme and ensure that it was possible to reuse the enzyme at least four times and maintain around $40 \%$ of the initial activity (Figure 5).

\section{CONCLUSION}

Bacterial cellulose and fungal laccase are biomacromolecules generated from microorganisms and in this study complete integration of these two molecules by using a simple and convenient method was performed successfully for the first time. Two different immobilization methods including physical adsorption and adsorption-crosslinking were compared. The results indicated that natural nanostructured BC membranes were possible to use as a support to immobilize $T$. versicolor laccase. The crosslinking-immobilized enzyme exhibited broader $\mathrm{pH}$ operation range of high catalytic activity and higher running stability compared with the free and adsorptionimmobilized enzymes, which is crucial for practical applications. The immobilized enzyme proved to be stable and retained 69\% of the original activity after recycling seven times. The improved reusability of laccase by immobilization would help cut down 
the running cost and make the enzymatic process economically feasible in an industrial scale. The advantages of using BC membranes as supports for enzyme immobilization include the following points. First, an open fiber network is ideal for immobilizing enzymes capable of reacting with diffusing species while allowing passage of soluble products with slight retardation. Second, the BC membrane has excellent wet mechanical strength compared to other polysaccharide hydrated membranes, which is a benefit for long-term running in film bioreactors. Novel applications of the BC-immobilized enzyme tentatively include active packaging, construction of biosensors for determination of phenols, as well as establishment of bioreactors for treatment of waste water/industrial effluent and for other catalytic reactions. Currently, BC is not cheap, but many research groups, including our, are making important attempts to decrease the production cost of the material. It is believed that $\mathrm{BC}$ will become inexpensive in a not far future.

\section{REFERENCES}

Arica, M. Y., Altintas, B., and Bayramoğlu, G. (2009). Immobilization of laccase onto spacer-arm attached non-porous poly(GMA/EGDMA) beads: application for textile dye degradation. Bioresour. Technol. 100, 665-669. doi: 10.1016/j.biortech.2008.07.038

Atalla, R. H., and Vanderhart, D. L. (1984). Native cellulose: a composite of two distinct crystalline forms. Science 223, 283-285. doi: $10.1126 /$ science.223.4633.283

Bautista, F. L., Morales, G., and Sanz, R. (2010). Immobilization strategies for laccase from Trametes versicolor on mesostructured silica materials and the application to the degradation of naphthalene. Bioresour. Technol. 101, 8541-8548. doi: 10.1016/j.biortech.2010.06.042

Bayramoglu, G., Gursel, I., Yilmaz, M., and Arica, M. Y. (2012). Immobilization of laccase on itaconic acid grafted and $\mathrm{Cu}(\mathrm{II})$ ion chelated chitosan membrane for bioremediation of hazardous materials. J. Chem. Technol. Biotechnol. 87, 530-539. doi: $10.1002 /$ jctb. 2743

Bielecki, S., Krystynowicz, A., Turkiewicz, M., and Kalinowska, H. (2002). "Bacterial cellulose," in Biopolymers (Polysaccharides I: Polysaccharides from Prokaryotes), Vol. 5, eds J. Vandamme, S. D. Baets, and A. Steinbüchel (Weinheim: Wiley-VCH Verlag), 37-90.

Bradford, M. (1976). A rapid and sensitive method for the quantitation of microgram quantities of protein utilizing the principle of protein-dye binding. Anal. Biochem. 72, 248-255. doi: 10.1016/0003-2697(76)90527-3

Cañas, A. I., and Camarero, S. (2010). Laccases and their natural mediators: biotechnological tools for sustainable eco-friendly processes. Biotechnol. Adv. 28, 694-705. doi: 10.1016/j.biotechadv.2010.05.002

Cavka, A., Guo, X., Tang, S., Winestrand, S., Jönsson, L. J., and Hong, F. (2013). Production of bacterial cellulose and enzyme from waste fiber sludge. Biotechnol. Biofuels. 6:25. doi: 10.1186/1754-6834-6-25

Chawla, S., Rawal, R., Shabnam, K. R. C., and Pundir, C. S. (2011). An amperometric polyphenol biosensor based on laccase immobilized on epoxy resin membrane. Anal. Methods 3, 709-714. doi: 10.1039/c0ay $00679 \mathrm{c}$

Chen, L., Hong, F., Yang, X. X., and Han, S. F. (2013). Biotransformation of wheat straw to bacterial cellulose and its mechanism. Bioresour. Technol. 135, 464-468. doi: 10.1016/j.biortech.2012.10.029

Couto, S. R., and Toca-Herrera, J. L. (2006). Industrial and biotechnological applications of laccases: a review. Biotechnol. Adv. 24, 500-513. doi: 10.1016/j.biotechadv.2006.04.003

Cristovao, R. O., Tavares, A. P. M., Brigida, A. I., Loureiro, J. M., Boaventura, R. A. R., Macedo, E. A., et al. (2011). Immobilization of commercial laccase onto green coconut fiber by adsorption and its application for reactive textile dyes degradation. J. Mol. Catal. B Enzym. 72, 6-12. doi: 10.1016/j.molcatb.2011.04.014

\section{AUTHOR CONTRIBUTIONS}

FH designed and coordinated the study and revised the manuscript. LC and MZ contributed the preparation of the manuscript. MZ carried out the experiments and analyzed the results. All authors read and approved the final manuscript.

\section{ACKNOWLEDGMENTS}

The authors would like to thank the Fundamental Research Funds for the Central Universities (2232014A3-04), the Program for New Century Excellent Talents in University (NCET-12-0828), the Science and Technology Commission of Shanghai Municipality (15520720800), and the National Natural Science Foundation of China (No. 51373031) for financial support.

da Silva, A. M., Tavares, A. P. M., Rocha, C. M. R., Cristovao, R. O., Teixeira, J. A., and Macedo, E. A. (2012). Immobilization of commercial laccase on spent grain. Process Biochem. 47, 1095-1101. doi: 10.1016/j.procbio.2012.03.021

Focher, B., Palma, M. T., Canetti, M., Torri, G., Cosentino, C., and Gastaldi, G. (2001). Structural differences between non-wood plant celluloses: evidence from solid state NMR, vibrational spectroscopy and X-ray diffractometry. Ind. Crop. Prod. 13, 193-208. doi: 10.1016/S0926-6690(00)00077-7

Gama, M., Gatenholm, P., and Klemm, D. (2012). Bacterial Cellulose: A Sophisticated Multifunctional Material. (Boca Raton, FL: CRC Press), 1-304.

Gardossi, L., Poulsen, P. B., Ballesteros, A., Hult, K., Svedas, V. K., VasiæRacki, D., et al. (2010). Guidelines for reporting of biocatalytic reactions. Trends Biotechnol. 28, 171-180. doi: 10.1016/j.tibtech.2010.01.001

Georgieva, S., Godjevargova, T., Mita, D. G., Diano, N., Menale, C., Nicolucci, C., et al. (2010). Non-isothermal bioremediation of waters polluted by phenol and some of its derivatives by laccase covalently immobilized on polypropylene membranes. J. Mol. Catal. B Enzym. 66, 210-218. doi: 10.1016/j.molcatb.2010.05.011

Guo, X., Cavka, A., Jönsson, L. J., and Hong, F. (2013). Comparison of methods for detoxification of spruce hydrolysate for bacterial cellulose production. Microb. Cell Fact. 12:93. doi: 10.1186/1475-2859-12-93

Guo, X., Chen, L., Tang, J., Jönsson, L. J., and Hong, F. F. (2015). Production of bacterial nanocellulose and enzyme from [AMIM]Cl-pretreated waste cotton fabrics: effects of dyes on enzymatic saccharification and nanocellulose production. J. Chem. Technol. Biotechnol. (in press). doi: 10.1002/jctb.4738

Hong, F., Guo, X., Zhang, S., Han, S. F., Yang, G., and Jönsson, L. J. (2012). Bacterial cellulose production from cotton-based waste textiles: enzymatic saccharification enhanced by ionic liquid pretreatment. Bioresour. Technol. 104, 503-508. doi: 10.1016/j.biortech.2011.11.028

Hong, F., Jönsson, L. J., Lundquist, K., and Wei, Y. (2006). Oxidation capacity of laccases and peroxidases as reflected in experiments with methoxysubstituted benzyl alcohols. Appl. Biochem. Biotechnol. 129, 303-319. doi: 10.1385/ABAB:129:1:303

Hong, F., Meinander, Q. N., and Jönsson, L. J. (2002). Fermentation strategies for improved heterologous expression of laccase in Pichia pastoris. Biotechnol. Bioeng. 79, 438-449. doi: 10.1002/bit.10297

Hong, F., Wei, B., and Chen, L. (2015). Preliminary study on biosynthesis of bacterial nanocellulose tubes in a novel double-silicone-tube bioreactor for potential vascular prosthesis. BioMed. Res. Inter. 9:560365. doi: 10.1155/2015/ 560365

Hong, F., Yang, X., Yang, G., and Cao, Z. (2010). Method for preparing immobilized enzyme by taking bacterial cellulose bead/membrane as vector. China Patent CN101967471/CN20101531814. Available at: http://worldwide.espacenet.com/

Hong, F., Zhu, Y. X., Yang, G., and Yang, X. X. (2011). Wheat straw acid hydrolysate as a potential cost-effective feedstock for production of bacterial cellulose. J. Chem. Technol. Biotechnol. 86, 675-680. doi: 10.1002/jctb.2567 
Hu, X. K., Zhang, Y., Zhao, X. H., and Hwang, H. M. (2007). Biodegradation of benzo[a]pyrene with immobilized laccase: genotoxicity of the products in HaCat and A3 cells. Environ. Mol. Mutagen. 48, 106-113. doi: 10.1002/em.20278

Jiang, G., Qiao, J., and Hong, F. (2012). Application of phosphoric acid and phytic acid doped bacterial cellulose as novel proton-conducting membranes to PEMFC. Int. J. Hydrogen Energy 37, 9182-9192. doi: 10.1016/j.ijhydene.2012.02.195

Jiang, G., Zhang, J., Qiao, J., Jiang, Y., Zarrin, H., Chen, Z., et al. (2015). Bacterial nanocellulose/nafion composite membranes for low temperature polymer electrolyte fuel cells. J. Power Sources 273, 697-706. doi: 10.1016/j.jpowsour.2014.09.145

Klemm, D., Schumann, D., Kramer, F., Heßler, N., Hornung, M., Schmauder, H. P., et al. (2006). Nanocelluloses as innovative polymers in research and application. Adv. Polym. Sci. 205, 49-96. doi: 10.1007/12_097

Kudanga, T., Nyanhongo, G. S., Guebitz, G. M., and Burton, S. (2011). Potential applications of laccase-mediated coupling and grafting reactions: a review. Enzyme Microb. Technol. 48, 195-208. doi: 10.1016/j.enzmictec.2010.11.007

Labus, K., Gancarz, I., and Bryjak, J. (2012). Immobilization of laccase and tyrosinase on untreated and plasma-treated cellulosic and polyamide membranes. Mater. Sci. Eng. C 32, 228-235. doi: 10.1016/j.msec.2011.10.023

Litescu, S. C., Eremia, S., and Radu, G. L. (2010). Biosensors for the determination of phenolic metabolites. Adv. Exp. Med. Biol. 698, 234-240. doi: 10.1007/978-14419-7347-4_17

Majeau, J. A., Brar, S. K., and Tyagi, R. D. (2010). Laccases for removal of recalcitrant and emerging pollutants. Bioresour. Technol. 101, 2331-2350. doi: 10.1016/j.biortech.2009.10.087

Makas, Y. G., Kalkan, N. A., Aksoy, S., Altinok, H., and Hasirci, N. (2010). Immobilization of laccase in $\kappa$-carrageenan based semiinterpenetrating polymer networks. J. Biotechnol. 148, 216-220. doi: 10.1016/j.jbiotec.2010.05.011

Moccelini, S. K., Franzoi, A. C., Vieira, I. C., Dupont, J., and Scheeren, C. W. (2011). A novel support for laccase immobilization: cellulose acetate modified with ionic liquid and application in biosensor for methyldopa detection. Biosens. Bioelectron. 26, 3549-3554. doi: 10.1016/j.bios.2011.01.043

Munari, F. M., Gaio, T. A., and Dillon, A. J. P. (2007). Phenol degradation and colour removal in submerged culture of Pleurotus sajor-caju with paper mill effluents. Biocatal. Biotransform. 25, 24-28. doi: 10.1080/10242420600906355

Osma, J. F., Toca-Herrera, J. L., and Rodríguez-Couto, S. (2010). Transformation pathway of Remazol Brilliant Blue R by immobilised laccase. Bioresour. Technol. 101, 8509-8514. doi: 10.1016/j.biortech.2010.06.074

Petersen, N., and Gatenholm, P. (2011). Bacterial cellulose-based materials and medical devices: current state and perspectives. Appl. Microbiol. Biotechnol. 91, 1277-1286. doi: 10.1007/s00253-011-3432-y

Plagemann, R., Jonas, L., and Kragl, U. (2011). Ceramic honeycomb as support for covalent immobilization of laccase from Trametes versicolor and transformation of nuclear fast red. Appl. Microbiol. Biotechnol. 90, 313-320. doi: 10.1007/s00253-010-3038-9

Reinhammar, B. (1997). "Kinetic studies on Polyporus and tree laccases," in Multi-Copper Oxidases, ed. A. Messerschmidt (Singapore: World Scientific), $167-200$.
Rekuć, A., Bryjak, J., Szymańska, K., and Jarzębski, A. B. (2009). Laccase immobilization on mesostructured cellular foams affords preparations with ultra high activity. Process Biochem. 44, 191-198. doi: 10.1016/j.procbio.2008.10.007

Rita, A., Casal, M., and Cavaco-Paulo, A. (2008). Application of enzymes for textile fibres processing. Biocatal. Biotransform. 26, 332-349. doi: $10.1080 / 10242420802390457$

Riva, S. (2006). Laccases: blue enzymes for green chemistry. Trends Biotechnol. 24, 219-226. doi: 10.1016/j.tibtech.2006.03.006

Sani, A., and Dahman, Y. (2010). Improvements in the production of bacterial synthesized biocellulose nanofibres using different culture methods. J. Chem. Technol. Biotechnol. 85, 151-164. doi: 10.1002/jctb.2300

Shah, J., and Brown, R. M. Jr. (2005). Towards electronic displays made from microbial cellulose. Appl. Microbiol. Biotechnol. 66, 352-355. doi: 10.1007/s00253-004-1756-6

Sokolnicki, A. M., Fisher, R. J., Harrah, T. P., and Kaplan, D. L. (2006). Permeability of bacterial cellulose membranes. J. Membr. Sci. 272, 15-27. doi: 10.1016/j.memsci.2005.06.065

Tang, J., Bao, L., Li, X., Chen, L., and Hong, F. F. (2015). Potential of PVA-doped bacterial nano-cellulose tubular composites for artificial blood vessels. J. Mater. Chem. B 3, 8537-8547. doi: 10.1039/c5tb01144b

Wang, F., Guo, C., Yang, L. R., and Liu, C. Z. (2010). Magnetic mesoporous silica nanoparticles: fabrication and their laccase immobilization performance. Bioresour. Technol. 101, 8931-8935. doi: 10.1016/j.biortech.2010.06.115

Wei, B., Yang, G., and Hong, F. (2011). Preparation and evaluation of a kind of bacterial cellulose dry films with antibacterial properties. Carbohydr. Polym. 84, 533-538. doi: 10.1016/j.carbpol.2010.12.017

Wu, S. C., and Lia, Y. K. (2008). Application of bacterial cellulose pellets in enzyme immobilization. J. Mol. Catal. B Enzym. 54, 103-108. doi: 10.1016/j.molcatb.2007.12.021

Zhang, H., Xun, E., Wang, J., Chen, G., Cheng, T., Wang, Z., et al. (2012). Immobilization of laccase for oxidative coupling of trans-resveratrol and its derivatives. Int. J. Mol. Sci. 13, 5998-6008. doi: 10.3390/ijms13055998

Zhao, M., Wang, Y., Liu, Z., Cui, D., and Bian, X. (2011). Properties of immobilized laccase on mesostructured cellular foam silica and its use in dye decolorization. J. Macromol. Sci. Part A Pure Appl. Chem. 48, 447-453. doi: 10.1080/10601325.2011.573330

Zhu, Y. F., Kaskel, S., Shi, J. L., Wage, T., and Pée, K. H. (2007). Immobilization of Trametes versicolor laccase on magnetically separable mesoporous silica spheres. Chem. Mater. 19, 6408-6413. doi: 10.1021/cm071265g

Conflict of Interest Statement: The authors declare that the research was conducted in the absence of any commercial or financial relationships that could be construed as a potential conflict of interest.

Copyright (C) 2015 Chen, Zou and Hong. This is an open-access article distributed under the terms of the Creative Commons Attribution License (CC BY). The use, distribution or reproduction in other forums is permitted, provided the original author(s) or licensor are credited and that the original publication in this journal is cited, in accordance with accepted academic practice. No use, distribution or reproduction is permitted which does not comply with these terms. 